\title{
Digital Transformations in Regional Economies During the COVID-19 Pandemic
}

\author{
Irina Turgel ${ }^{1, *}$ Olga Chernova ${ }^{2,}$ Dina Williams ${ }^{3}$
}

\author{
${ }^{1}$ Ural Federal University, Russia \\ ${ }^{2}$ Southern Federal University, Russia \\ ${ }^{3}$ Consulting company, Enterprise Action Consulting \& Training Ltd, Great Britain \\ *Corresponding author. Email: i.d.turgel@urfu.ru
}

\begin{abstract}
This paper sets out to investigate the effects of the COVID-19 pandemic on digital transformations in the economy of Russian regions. The authors believe that, during this challenging period, the transfer of various types of economic relations and interactions to a digital format becomes an important factor in preserving the social and economic potential of regions and increasing the level of business survival. The aim of the paper is to study the trends of digital transformations in the economy of Russian regions, caused by the COVID-19 pandemic, as well as to identify the factors determining the readiness of regions to develop digitalisation processes. The methodology of the study involves the concept of intensive and extensive application of information and communication technologies and the theory of shocks. The empirical basis of the study relies on data provided by international organisations (ILO, OECD, WorldBank, ITC) andthe Federal State Statistics Service, analytical reports of international and Russian consulting, audit and expert organisations (McKinsey, FinExpertiza, RBC, NAFI), as well as on live data posted on official websites managed by public authorities of the constituent entities of the Russian Federation. The study of digital transformations at the procedural, institutional and business levels demonstrated that the vector of digital transformations in regional economies is expressed in the orientation towards the formation of business and manufacturing ecosystems, with a change in the process of value creation from the value proposition of products to the value proposition of services. The conducted analysis enabled the authors to evaluate the readiness of regional economies to implement digital transformations. It is concluded that the development of these processes is associated with active governmental support for the implementation of complex projects directed at the digitalisation of regional economies.
\end{abstract}

Keywords: digital ecosystem, regional development, pandemic, digitalisation.

\section{INTRODUCTION}

The COVID-19 pandemic, affecting both developed and developing regions, has had serious social and economic consequences due to the restriction of business activity and the introduction of quarantine measures.

According to various sources, the Global GDP is expected to contract by $4.6 \%$ [1] or 5.2 [2] in 2020. In the globalised economy, the impact of the pandemic is seen in a disrupted global supply chain and, as a result, in a global trade. The international trade is expected to shrink by $8 \%$ [1] or even by $13.4 \%$ [2]. Severe and voluntary restraints on human interaction adopted to curb the spread of the virus have affected employment. According to OECD [1], unemployment is expected to reach nearly $10 \%$ worldwide. According to the ILO estimates, $93 \%$ of the global workforce ( 2.7 billion workers) is affected by full or partial lockdown measures. The latest data suggest that during the first quarter of 2020 , an estimated $5.4 \%$ of global working hours were lost, an equivalent to 155 million full-time jobs. The deepest recession is expected in commodity-dependent regions such as emerging and developing economies in Europe and Central Asia, especially those that rely on the export of energy, industrial commodities and metal.

The losses of the Russian economy are estimated by experts at 100 billion rubles per day, the drop in trade turnover has already reached $80 \%{ }^{1}$.

\footnotetext{
${ }^{1}$ Kommersant, available at: https://www.kommersant.ru/doc/4331781
} 
The Russian Federation's economy is forecast to contract by $6.0 \%$ in 2020 this year, reflecting an upsurge in COVID-19 cases and the collapse in oil prices [3].

In this context, the transfer of various types of economic relations and interactions to a digital format has become an important factor in preserving the social and economic potential of the regions and increasing the level of business survival. Government bodies, educational and medical institutions, the services sector, financial structures, and population have also become participants in digitalisation.

According to the authors, digitalisation offers a significant potential for social and economic development of regions in the face of external challenges. However, the success of digital transformations largely depends on how synchronized these processes are at different levels: procedural (implementation of new digital tools and technologies), institutional (formation and consolidation of new interaction rules, new roles of economic agents) and business level (formation of new business models, a new mechanism for creating added value). That is, modern digital transformations are meant to manifest themselves in the consistent complex formation of the regional ecosystem. This is a rather complex process that requires an understanding of the factors and conditions that determine its effectiveness and direction of development. The aim of the paper is to study the trends of digital transformations in the economy of Russian regions, caused by the factors of the COVID19 pandemic, as well as to identify the factors that determine the readiness of regions to develop digitalisation processes.

\section{METHODOLOGY}

This study rests onthe idea of the digital economy as a specific sphere of economic relations mediated by the Internet, cellular communications and other modern ICTs [4], while digitalisation is viewed as a new paradigm of accelerated economic development, where information is the main factor of growth. An important feature of any information resource is that, existing in digital form, this resource allows a huge amount of data to freely move through digital devices within the shortest possible time between people in different parts of the world [5].

The study of digitalisation processes in regional systems is a matter of scientific interest for a fairly large number of national and foreign scientists. In describing digitalisation trends, the following main aspects can be distinguished: the development of information infrastructure $[6,7,8,9]$, the formation of institutional conditions for the implementation of digital transformations [10,11, 12, 13, 14], the development of information literacy of users [15]. Almost all researchers refer to through digitalisation of a company's physical assets and of a wide range of production and business processes as the main attribute of digital transformations. In the study of digitalisation trends, the authors rest on the concept of intensive and extensive use of ICT [16], according to which the subject of research is the processes of transformation in existing types of economic activity as a result of application of modern ICTs (intensive use), as well as a quantitative change in the types and spheres of activity, where ICTs is applied (extensive use).

The study is grounded on data from international organisations (OECD, World Bank, ITC), which characterise the development of the pandemic and its social and economic consequences at the global level and in the context of individual countries; data from the Federal State Statistics Service, characterising the social and economic situation in Russian regions; analytical reports of international and Russian consulting, audit and expert organisations, including McKinsey, FinExpertiza, RBC, NAFI; live data posted on the official websites managed by public authorities of the constituent entities of the Russian Federation.

\section{RESULTS}

\subsection{Impact of the COVID-19 pandemic on the economy of a region}

The ripple effect of COVID-19 pandemic is apparent across all sectors of the economy.

To a greater extent, enterprises that were unable, due to a number of reasons, to transfer their business from offline to online turned out to be susceptible to the negative impact. Thus, according to the forecast estimates of the National Rating Agency, the consequences of the crisis have mostly affected the following areas: services (77\% reduction in added value), clothing and footwear production $(52.7 \%$ reduction in added value), culture and sports, leisure and entertainment $(46.1 \%$ reduction in added value $)^{2}$.

The economic impact of the pandemic on SMEs is not only limited to the increased unemployment, but also has systemic implications. Although some of enterprises might be relatively inefficient, the nimbler ones can play a role in supply chains that would be hard to duplicate. Yet many of them have been shaken by serious disruptions in a way how people communicate, work, produce, trade, consume and live. The COVID-19 pandemic affects enterprises on both the supply and demand sides. Due to workers' illness, compulsory and voluntary absenteeism, as well as restrictions in movement of people, enterprises experience a reduction in the supply of labour. On demand side, enterprises face

\footnotetext{
${ }^{2}$ Source: National Rating Agency, available at: https://www.ranational.ru/ru/node/63643
} 
a sudden drop in consumer spending and consumption due to the loss of income, fear of contagion and heightened uncertainty.

So far, only limited and fragmented evidence has been available on the impact of COVID-19 pandemic crisis on SMEs across the world. Some global organisations, such as OECD and the International Trade Center, have conducted worldwide surveys. Further evidence is available from the USA and the UK.

According to the survey conducted by the International Trade Center [17], 55\% of SMEs reported being affected by the pandemic and the measures taken to contain it. Unsurprisingly, smaller companies are affected more than the larger ones (see Fig 1).

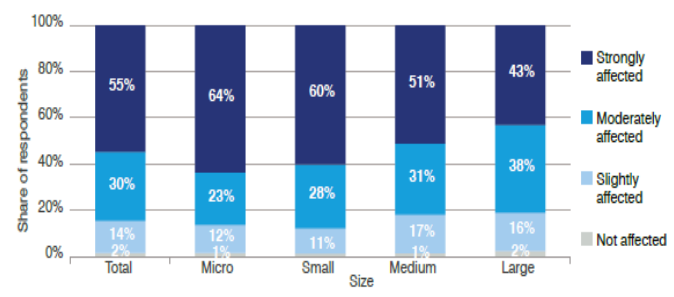

Figure 1 Impact of COVID-19 on Small Businesses [13]

OECD compiled the results of surveys carried out in different countries over the period from February to May 2020. Although the data varies from country to country, it indicates that more than $50 \%$ of the SMEs bear the brunt of the crisis with revenue lost, and a third of SMEs fears to fail without support. In North America (the USA and Canada) $90 \%$ of SMEs are affected by COVID-19 and lack reserves to survive longer than a few weeks; in the Netherlands, $85 \%$ of SMEs are in financial difficulties and $20 \%$ are at serious risk; in Germany, the most robust Eurozone economy and a country with a relatively low mortality rate from COVID-19, 58\% of SMEs experienced a 50\% drop in turnover and over $50 \%$ of SMEs have only a few months of liquidity reserves left [1].

According to the survey conducted by McKinsey between March and May 2020, 56\% of SMEs in the US reported being affected by COVID-19 [18]. Furthermore, $31 \%$ of American SMEs had temporarily stopped operating and by mid-May more than half had laid off or furloughed employees [19]. According to the data analysis conducted by McKinsey (2020), up to $36 \%$ of SMEs could close permanently as a result of the disruption from just the first months of the pandemic. The pandemic has not only interrupted the life of SMEs, but also had a knock-off effect on business confidence. Smallercompanies are becoming ever more uncertain about their prospects. If at the beginning of the pandemic early March 2020 nearly $70 \%$ of the US small businesses expected to recover fully within two years, by the end of May this number dropped to $50 \%$.
In the UK, where SMEs account for $99 \%$ of all British businesses [20], $50 \%$ of the total business revenue and $44 \%$ of the workforce (Albonico et al., 2020), two-thirds of SMEs forced to a temporary closure at the beginning of the lockdown measures. According to a recent McKinsey online survey [21], $80 \%$ of the SMEs reported a decline in revenue. With low confidence in the overall strength of the economy, the early May survey indicates that nearly $20 \%$ of the surveyed SMEs expect to be out of business by August 2020; that figure increases to $60 \%$ for April 2021, this is in comparison to an earlier survey in April 2020 when $80 \%$ of surveyed SMEs did not expect to survive a year. However, this data of McKinsey survey somewhat contradicts to the survey conducted by Simply Business insurance company which collected data from 3,700 small business and self-employed people in the UK. According to the Simply Business survey [20], $41 \%$ of small business owners fear their business is at risk of permanently closing due to the pandemic; $14 \%$ believe they will likely close within one to three months; $12 \%$ fear they will close within three to six months; $11 \%$ think they will close within six months to a year. Furthermore, $4 \%$ of surveyed SMEs reported to being permanently closed due to the pandemic. At the same time, the survey shows signs of resilience in the SMEs. A fifth of the SMEs is feeling optimistic about the life after the pandemic and $75 \%$ are determined to continue / resume their business.

It is noteworthy that the economic impacts of the crisis are likely to be multidimensional: immediate, near and long term effects, variations across sectors and different regions even within the same country. According to the International Labour Organisation [22], the sectors mostly impacted by the pandemic and lockdown measures are accommodation and food services, manufacturing, wholesale and retail business, real estate and other service-based activities that involve direct interaction with customers. 1.25 billion workers are employed in these sectors ( $38 \%$ of the global workforce). According to the OECD report (2020), the share of SMEs in employment in these sectors is $75 \%$ and nearly $90 \%$ in Greece and Italy. A further McKinsey study on the impact of COVID-19 on employment in Europe revealed that $70 \%$ of SME jobs at risk are in the accommodation and food sector, $56 \%$ - in the wholesale and retail sector, $75 \%$ - in the real-estate sector, $76 \%$ in the construction sector, and $68 \%$ - in the professional-service sector. Furthermore, the recent Brookings report [23] segmented industries into three categories depending on the depth of the economic risk from the COVID-19 pandemic. According to the data, $26 \%$ of SMEs in the USA are in the immediate risk categories which include businesses in hospitality, food services, art and entertainment, personal services (e.g. hairdressers), and retail. Another $28 \%$ of SMEs are in the near-term risk category which consists of such industries as construction, logistics, media, wholesale. Similarly in the UK, the sectors 
experiencing the most immediate distress include those businesses which provide non-essential face-to-face physical service delivery in leisure, hospitality, transport services and non-food retailing. According to the McKinsey survey, more than $90 \%$ of observed SMEs in logistics, construction, and agriculture reported reductions in revenue; the least affected SMEs are those in scientific, finance, insurance, and education sectors [21].

\subsection{Vector of digital transformations in the economy of region}

On the 28th of March, most regions of Russia introduced 'Recommended Restrictive Measures' due to the situation with COVID-19. This was a de facto lockdown for a large part of the Russian economy, even though certain sectors were excluded and regional governors were given broad discretion on the implementation of control measures.

The RSBI (Russia Small Business Index) suggests that $15 \%$ have closed their businesses (4\% permanently) and $36 \%$ were considering to terminate business completely in case the demand is not improving. However, over a quarter of businesses (27\%) reported having sufficient reserves to weather the storm.

These reserves are largely associated with the deployment of digitalisation processes at various levels of management and in different areas, where economic relations are mediated by the Internet and modern information and communication technologies.

Digital transformations at the procedural level are expressed in an increase in the volume of digital data as various types of interactions are transferred to the digital space. Thus, according to the Mediascope study, Internet usage has increased by $12 \%$ during the pandemic ${ }^{3}$. Videoconferences, various customer services and entertainment sites have become the most popular. Accordingly, the burden on the resources of companies providing these services has increased significantly. It should be noted that, against the background of information that the coronavirus can spread through cash, a significant part of operations began to be carried out using Internet services and bankcards.

At the institutional level, trends in the development of digitalisation processes can be explored from the perspective of the activities of government bodies (including regional) in terms of promoting the latest technologies and stimulating their use in all fields. For example, in the Rostov region, financial support has been provided to companies for their online promotion starting from July 10, 2020 (promotion of an online store - up to 200 thousand rubles, trading on marketplaces -150 thousand rubles for Russian sites and 300 thousand rubles

${ }^{3}$ Source: Mediascop WEB-index, 2020, available at: https://webindex.mediascope.net/research
- for foreign ones; promotion on the Instagram - up to 30 thousand rubles) ${ }^{4}$. Undoubtedly, the formation and development of the institutional environment of a region cannot be relied exclusively on government support. Thus, in most European countries, major corporations, changing the business standards, are the conductors of the latest achievements in digitalisation.

At the business level, one can observe an intensification of digitalisation processes in the Russian regions, which is reflected in solving problems of digitalisation of business processes in the field of sales, analytics and forecasting. At the same time, a significant part of employees in the management sphere is reoriented to a remote mode of work. Online customer service (especially in banking) is considered to be undisputable leader in digitalisation. In the field of culture, initiatives of creating virtual exhibitions, concert halls and other projects are being launched. Distance technologies are being actively implemented in the educational field. Under the COVID-19 pandemic the lack of demand for manufactured products and provided services, the absence of competitiveness is compensated by many companies through the development of servitisation processes based on digital technologies.

Thus, the vector of digital transformations in the economies of region is expressed in the formation of organisational ecosystems and industrial enterprises with a change in the process of value creation. This is reflected in the transition from the value proposition of products to the value proposition of services.

\subsection{Factors that determine the readiness of regions for digital transformation}

The digital transformation of the economy of region is a complex and complicated process of gradual transition from a traditional model of business processes to a digital model. In order to make this process effective, a certain level of business technological maturity is required, which provides a basis for digital transformation. However, the rapid spread of coronavirus infection intensified digital transformations, which resulted in a bunch of problems caused by a different level of readiness to such changes.

Assessing the readiness of a regional economy for digital transformations, it is reasonable to distinguish the following components in which the implementation of economic relations mediated by modern ICTs is carried out:

- $\quad$ sphere of vital activity of the population;

- sphere of industrial production and services sector;

- information environment of the region.

${ }^{4}$ Source:The Rostov Region Government website, available at: https://www.donland.ru/news/9906/ 
An analysis of the penetration of modern information technologies into the daily activities of citizens revealed that all regions of Russia as a whole are characterised by an increase in the Internet audience, as evidenced by an increase in the proportion of the population using the Internet (Table 1). developing: regional programmes for digital economic development of Russian regions have been approved; the infrastructure of broadband Internet access is expanding.

In general, one can say that the population of Russian regions is increasingly using Internet resources. Purchases, especially under conditions of lockdown, are

Table 1. Internet access of households in the Russian Federation regions, \% [24]

\begin{tabular}{|l|c|c|}
\hline \multicolumn{1}{|c|}{ Region } & $\mathbf{2 0 1 7}$ & $\mathbf{2 0 1 8}$ \\
\hline Central Federal District & 77.5 & 78.3 \\
\hline Northwestern Federal District & 79.3 & 79.3 \\
\hline Southern Federal District & 79.1 & 76.9 \\
\hline North Caucasian Federal District & 78.3 & 74.7 \\
\hline Volga Federal District & 74.0 & 74.9 \\
\hline Ural Federal District & 75.6 & 77.1 \\
\hline Siberian Federal District & 72.2 & 72.9 \\
\hline Far Eastern Federal District & 76.6 & 77.6 \\
\hline
\end{tabular}

Table2.Internet usage by organisations and enterprises in Russian regions, \% [24]

\begin{tabular}{|l|c|}
\hline \multicolumn{1}{|c|}{ Region } & $\mathbf{2 0 1 7}$ \\
\hline Central Federal District & 92.4 \\
\hline Northwestern Federal District & 93.3 \\
\hline Southern Federal District & 93.4 \\
\hline North Caucasian Federal District & 93.1 \\
\hline Volga Federal District & 91.6 \\
\hline Ural Federal District & 85.7 \\
\hline Siberian Federal District & 83.9 \\
\hline Far Eastern Federal District & 91.2 \\
\hline
\end{tabular}

Searching information about goods and services is one of the main purposes of using the Web. It should be noted that the indicator of Internet use for this purpose increased from $43.8 \%$ to $54.1 \%$ in 2018 in comparison with 2016. Today about $40 \%$ of the population uses the Internet to order goods and services [24].

Digital technologies have already been used in the field of industrial production, although complex digitalisation projects in the regions are rare. Typically, sales, analytics and forecasting are digitised. The banking sector dominates in the service sector. In the entire business sector, the Internet is mostly used by manufacturing enterprises (77.2\%). Regarding commercial usage of the Internet, the priority is given to contacts with suppliers (73.1\% of organisations). $51.7 \%$ of companies use the Internet to communicate with customers [24].

The indicators of Internet usage by organisations and enterprises in Russian regions are presented in Table 2.

The information environment of regions can be assessed, first of all, in reliance on the indicators of infrastructural support for digitalisation processes. In Russian regions, the creation of infrastructure is mainly supported by MTS, Rostelecom, T2 Mobile and Megafon mobile operators, as well as by the Russian Post. The institutional environment of digitalisation is rapidly gradually shifting into online. At the same time, the use of ICT in regional industries remains limited, particularly in small and medium-sized businesses. This is due to the insufficient level of material and technical equipment of companies, as well as the lack of financial resources for the implementation of digitalisation projects. During the pandemic, digital communication processes are developing most actively in the online interactions of suppliers and consumers, as well as in remote employment of specialists engaged in the administrative sector.

\section{CONCLUSIONS}

The COVID-19 pandemic and lockdown measures that followed have had a significant impact on the economy of Russian regions.

In the context of the COVID-19 pandemic, digital economic transformation is becoming the dominant feature of regional development. The formation of digital ecosystems in a region is manifested in the emergence of new business models that digitise the relationships and processes occurring both within companies and between companies and the external environment. In addition, goods and services are gaining an immaterial form, which acquires certain advantages over a material product. 
However, implementation of digitalisation projects is limited due to the low profitability of enterprises and organisations, especially small and medium-sized businesses (which, at the same time, turned out to be the most vulnerable in the pandemic). The authors of the paper believe that these processes can be promoted by active governmental support and the development of the IT sector

\section{AUTHORS' CONTRIBUTIONS}

This article is the result of collaborative research. I. Turgel and O. Chernova conceived the presented idea and developed a conceptual framework for the study. I. Turgel formed the methodological basis of the research, conducted a literature review and analysis of problems. O. Chernova was responsible for the empirical research, as well as preparing recommendations and proposals. D. Williams analyzed the factors of the pandemic on the global economy.

\section{REFERENCES}

[1] OECD. SME Policy Responses, OECD Publishing, Paris, 2020, p. 135.

[2] World Bank, Global Economic Prospects, June 2020, The World Bank. DOI: https: //doi.org/10.1596/978-1-4648-1553-9.

[3] World Bank, Russia Economic Report \#43 Russia: Recession and Growth Under the Shadow of a Pandemic, No. 43, World Bank, 2020.

[4] M. Rouse, Digital Economy, Newton: Techtarget, 2016.

[5] D. Tapscott, The Digital Economy: Promise and Peril In The Age of Networked Intelligence,McGrawHill, 1995.

[6] M. Unguru, The Digital Gap In The Eu And The Perspectives For The Information Economy In Romania, Euroinfo, Institute for World Economy, Romanian Academy, 2017, 1 (1112), pp.87-95.

[7] Love, Peter E.D., Zhou, Jingyang, Matthews, Jane, Lavender, Matthew, Morse, Troy, Managing rail infrastructure for a digital future: Future-proofing of asset information, Transportation Research Part A: Policy and Practice, Elsevier, 110 (C), 2018, pp. 161-176.

[8] R. Kling, R. Lamb, IT and Organizational Change in Digital Economies. Understanding the Digital Economy (E. Brynjolfsson, B. Kahin (eds)), Cambridge: MIT Press, MA, 2000, pp. 295-324.
[9] P. Parviainen et al., Tackling the digitalization challenge: How to benefit from digitalization in practice, International journal of information systems and project management, 5 (1) (2017) 63-77.

[10]CE. Stegaroiu, The Importance Of Information Systems In The Management And Processing Of Large Data Volumes In Public Institutions, Annals - Economy Series, Constantin Brancusi University, Faculty of Economics 1 (2016) 140143.

[11] JT Bilal, Ensuring Transparency And Access To Information In The Management Of Public Institutions Through E-Government, "Proceedings of the international management conference, Faculty of Management, Academy of Economic Studies, Bucharest, Romania, 11 (1), 2017, pp. 88-98.

[12]E.V. Mikhalkina, O.A. Chernova, A.V Gozalova, Digitalization and the PrincipalAgent Problem in the Higher Education. In: T. Kolmykova, E. Kharchenko (eds) Digital Future Economic Growth, Social Adaptation, and Technological Perspectives. Lecture Notes in Networks and Systems, 111. Springer, Cham, 2020, pp. 659-665.

[13] T. Savina, Tsifrovaya economika kak novaya paradigma razvitiya: vizovi, vozmojnisti i perspectivi (Digital Economy as a New Development Paradigm: Challenges, Opportunities and Prospects), Finance and Credit 24, 3 (771) (2018) 579-590.

[14]M. Polozhikhina, Ekonomika regionov: problemi i puti ikh resheniya (Regional Economy: Problems and Solutions), Social Sciences and Humanities: Domestic and Foreign Literature. Serious 2, Economy: Abstract journal 4 (2018) 229-235.

[15] O. Demushina, Elektronnoye uchastiye grajdan: regionalniy uroven (na primere Volgogradskoy oblasti) (Citizen Electronic Participation: regional level (on the example of the Volgograd region), World of Economics and Management, 17 (4) (2017) 190-200.

[16] J. Haltiwanger, R. Jarmin, Measuring the Digital Economy. Understanding the Digital Economy (E. Brynjolfsson, B. Kahin (eds)) Cambridge: MIT Press, MA, 2000, pp. 13-33.

[17]ITC. (2020), SME Competitiveness Outlook 2020: COVID-19: The Great Lockdown and Its Impact on Small Business, International Trade Center, p. 172. 
[18] L. Anan, N. Jain, D. Mahajan, M. Maxwell, A. Pandher, Tracking the impact of coronavirus on US small businesses, McKinsey, 29 May, 2020.

[19] State of Small Business Report, Facebook and Small Business Roundtable, 2020, p. 35.

[20] S. Bromley, New coronavirus survey: impact set to cost UK small businesses $£ 69$ billion ", Simply Business, 28 May, 2020.

[21] M. Albonico, Z. Mladenov, R. Sharma, How the COVID-19 crisis is affecting UK small and medium-size enterprises | McKinsey ", 16 July, 2020.

[22] ILO, ILO Monitor: COVID 19 and the World of Work, No. Second Edition, ILO, 2020, p. 11.

[23] J.Parilla, S. Liu, B. Whitehead, How local leaders can stave off a small business collapse from COVID-19, Brookings, 3 April, 2020.

[24] Information Society Indicators in the Russian Federation. 2019, Data Book, Moscow: HSE University, 2019. 